\title{
Does CSR Disclosure Solve Social Conflicts Between Companies and Community? An Empirical Evidence
}

\author{
Anis Chariri ${ }^{1}$ \\ ${ }^{1}$ Universitas Diponegoro, Jl. Prof. H. Soedarto, S.H. Tembalang, 50275, Indonesia
}

\begin{abstract}
This study aimed to investigate whether CSR programs can be used by companies to solve social conflicts between companies and communities. We conducted empirical tests using data gathered from the society living in the areas closed to mining companies (Cilegon and Cilacap, Indonesia) and company managers - who responded to our survey. The findings showed that CSR disclosures have not been able to solve social conflicts between companies and the society. This study indicated that there are differences in the views of companies and communities on the importance of CSR programs. Indeed, CSR programs which are seen as important by the community are not considered as essential by the companies. This implies that the community is not seen by the companies as an important and powerful stakeholder. Consequently, social conflicts will continue to occur as long as the companies do not pay attention to the public interests.
\end{abstract}

\section{Keywords:Social Conflict; Social Responsibility; Community; Company.}

\section{Introduction}

The existence of companies in society can be seen as a social contract between the companies and the surrounding community. A company is considered as legitimate when the company provides benefits to the community and their environment. However, the reality shows that the existence of the company actually raises a variety of problems because companies provide the society with negative impact of their activities, may lead to social conflicts and disrupt harmony.

In Indonesia's environment, for example, the public has witnessed various social and environmental problems caused by company's activities and encouraged demonstrations (e.g Buyat Bay case, Freeport, Logging, Lapindo and others). These problems lead to the idea of corporate social responsibility (CSR). Consequently the issue of corporate social responsibility has been the concern of the business community and academia [1-5].

Studies that examine social and environmental disclosure indicated that CSR practices increase over time, both in the number of companies making disclosures and in the amount of information reported [5-11]. Several studies have also focused on motivations that encourage companies to disclose CSR, especially to get legitimacy from stakeholders [2,12,13]. However, the results of another study in the UK showed that companies in the UK have different reasons when issuing CSR reports [14].

It is true that previous studies have contributed some interesting findings on CSR disclosure, especially its determinants and consequences. However, it is not easy to find any studies exploring whether CSR disclosure can be used by companies as a medium to solve social conflicts with the society. Social conflict can be eliminated if there is a consensus between companies and community in regard to the CSR programs that should be disclosed in CSR Report. Therefore, this exploratory research aims to answer a question: does CSR disclosure can be used to solve social conflict among companies and communities? The results of this study are expected to contribute as follows. Firstly, it may assist the government in making regulations related to the implementation of corporate social responsibilities. Secondly, this study may help companies in Indonesia to be more concerned with social and environmental issues.

\section{Methodology}

The respondent of this study consisted of managers of mining companies listed on the Indonesia Stock Exchanges and the society inhabiting the areas closed to the companies (Cilacap and Cilegon areas). Questionnaires are based on the Global Reporting Initiative items mostly used by Indonesian mining companies. Such items are then adjusted to the CSR items used by Reference $[15,16]$ and the Ministry of Social Affairs Republic of Indonesia entitles "Guidelines on Criteria and Assessment of Corporate Social Responsibility", which resulted in three main aspects of CSR concerning the society: economic (eight indicators), community (eight indicators), and social 
(seven indicators), on a scale of 1 (very unimportant) to 5 (very important).

We distributed 500 and 350 questionnaires to respondents living in Cilacap and Cilegon and company managers respectively. Unfortunately, only 189 questionnaires were returned by the community (185 usable) and 44 questionnaires were received from company managers (41 usable). Independent Sample Tests are then used to examine whether there are different views between companies and communities on the importance of CSR programs.

\section{Discussion}

\subsection{Economic Aspects of CSR Disclosures}

From the economic aspect, CSR is associated with how much the company contributes to the economic activities benefited by the communities. Table 1 showed that six of eight indictors of economic aspects are significant $(\mathrm{p}<0.05)$. These figures imply that there are different views between the companies and communities on the importance of economic aspects as disclosed in the CSR reports.

Table 1. Independent Sample Tests: Economic Aspects Of CSR

\begin{tabular}{|c|c|c|c|c|}
\hline \multirow{2}{*}{$\begin{array}{c}\text { CSR Elements } \\
\text { (Economic Aspects) }\end{array}$} & $\begin{array}{c}\text { Levene's } \\
\text { Test for } \\
\text { Equality of } \\
\text { Variances }\end{array}$ & \multicolumn{2}{|c|}{$\begin{array}{c}\text { t-test for } \\
\text { Equality of } \\
\text { Means }\end{array}$} \\
\cline { 2 - 5 } & $\mathrm{F}$ & Sig. & $\mathrm{t}$ & Sig. \\
\hline $\begin{array}{l}\text { 1. Percentage of budget } \\
\text { allocation for CSR } \\
\text { Program }\end{array}$ & 3.999 & .047 & .365 & .716 \\
\hline $\begin{array}{l}\text { 2. Proportion of society } \\
\text { accepting economic } \\
\text { benefits }\end{array}$ & 4.335 & .038 & -2.660 & $.010^{*}$ \\
\hline $\begin{array}{l}\text { 3. Changes in community } \\
\text { welfare (individually } \\
\text { \& socially) }\end{array}$ & .256 & .614 & -3.151 & $.002^{*}$ \\
\hline $\begin{array}{l}\text { 4. Growth of community } \\
\text { economy institution } \\
\text { (small and mediums } \\
\text { size business) }\end{array}$ & .770 & .381 & -3.007 & $.003^{*}$ \\
\hline $\begin{array}{l}\text { 5. Entrepreneurship } \\
\text { training }\end{array}$ & .161 & .688 & -.592 & .554 \\
\hline $\begin{array}{l}\text { 6. Community } \\
\text { participation in CSR } \\
\text { program }\end{array}$ & .172 & .678 & -2.927 & $.004^{*}$ \\
\hline $\begin{array}{l}\text { 7. Supporting economy } \\
\text { programs offered by } \\
\text { the government }\end{array}$ & 2.441 & .120 & -2.900 & $.004^{*}$ \\
\hline $\begin{array}{l}\text { 8. Procedures for local } \\
\text { hiring and proportion } \\
\text { of senior management } \\
\text { hired from the local } \\
\text { community at } \\
\text { locations of significant } \\
\text { operation. }\end{array}$ & .470 & .493 & -2.900 & $.004^{*}$ \\
\hline Note: Significant at & & & & \\
\hline
\end{tabular}

Note: * Significant at $5 \%$

\subsection{Community Aspect of CSR Disclosures}

Table 2 explained the results of independent sample test to investigate whether there are different views between companies and the society on the importance of community activities of CSR programs. It can be seen from the Table that there are five of eight community aspects of CSR viewed differently by the companies and the society $(\mathrm{p}<0,05)$.

Table 2. Independent Sample Tests: Community Aspects Of CSR

\begin{tabular}{|c|c|c|c|c|}
\hline \multirow[t]{2}{*}{$\begin{array}{c}\text { CSR Elements } \\
\text { (Community Aspects) }\end{array}$} & \multicolumn{2}{|c|}{$\begin{array}{l}\text { Levene's } \\
\text { Test for } \\
\text { Equality of } \\
\text { Variances }\end{array}$} & \multicolumn{2}{|c|}{$\begin{array}{l}\mathrm{t} \text {-test for } \\
\text { Equality of } \\
\text { Means }\end{array}$} \\
\hline & $\mathrm{F}$ & Sig. & $\mathrm{t}$ & Sig. \\
\hline $\begin{array}{l}\text { 1. Funding activity for } \\
\text { social welfare }\end{array}$ & .669 & .414 & $\begin{array}{r}- \\
3.206\end{array}$ & $\begin{array}{c}.002 \\
*\end{array}$ \\
\hline $\begin{array}{l}\text { 2. Accepting internship } \\
\text { for students }\end{array}$ & .041 & .839 & 1.825 & .069 \\
\hline $\begin{array}{l}\text { 3. Funding for } \\
\text { community health } \\
\text { projects }\end{array}$ & $\begin{array}{r}1.10 \\
8\end{array}$ & .294 & 3.066 & $\begin{array}{c}.002 \\
*\end{array}$ \\
\hline $\begin{array}{l}\text { 4. Funding educational } \\
\text { activities } \\
\text { (scholarship) }\end{array}$ & .023 & .880 & 2.919 & $\begin{array}{c}.004 \\
*\end{array}$ \\
\hline $\begin{array}{l}\text { 5. Providing community } \\
\text { with an access to } \\
\text { company facilities }\end{array}$ & .030 & .863 & 2.615 & $\begin{array}{c}.010 \\
*\end{array}$ \\
\hline $\begin{array}{l}\text { 6. Supporting the } \\
\text { development of local } \\
\text { industry }\end{array}$ & .207 & .650 & $\begin{array}{r}- \\
1.838\end{array}$ & .067 \\
\hline $\begin{array}{l}\text { 7. The involvement of } \\
\text { local community }\end{array}$ & .019 & .891 & 2.113 & $\begin{array}{c}.036 \\
*\end{array}$ \\
\hline $\begin{array}{l}\text { 8. Number of } \\
\text { community accepting } \\
\text { benefits of CSR }\end{array}$ & $\begin{array}{r}4.98 \\
7\end{array}$ & .027 & -.338 & .736 \\
\hline
\end{tabular}

Note: * Significant at $5 \%$

Such different views indicated that there is no agreement between the companies and the communities regarding community aspects of CSR activities. This means that disclosure of community activities provided by the companies have not been able to solve social conflicts.

\subsection{Social Aspects of CSR Disclosures}

From the social aspects, CSR can be related to how much contribution given by the companies in supporting social activities (social welfare, health and culture). Table 3 shows that four of seven CSR items relating to social activities are differently viewed as important by the community and the companies. This implies that all social activities offered by the companies may not solve social conflicts because of different interests between companies and the communities.

The statistical test showed that in general not all elements of CSR activities (economics, community and social aspect) as disclosed in the company annual reports are considered as important by the companies and the society. Indeed, economic aspects (6 of 8 indicators), community aspects (5 of 8 indicators), and 
social aspects (4 of 7 indicators) are viewed by companies and society differently. The results indicated that CSR disclosure cannot be fully employed to mitigate social conflicts between companies and communities. This implies that CSR disclosure is merely prepared as a reflection of the emergence of social conflicts between capitalists and other groups such as workers, environmental groups, consumers, and others [17].

Table 3. Independent Sample Tests: Social Aspects Of CSR

\begin{tabular}{|c|c|c|c|c|}
\hline \multirow[t]{2}{*}{$\begin{array}{c}\text { CSR Elements (Social } \\
\text { Aspects) }\end{array}$} & \multicolumn{2}{|c|}{$\begin{array}{c}\text { Levene's } \\
\text { Test for } \\
\text { Equality of } \\
\text { Variances }\end{array}$} & \multicolumn{2}{|c|}{$\begin{array}{l}\text { t-test for } \\
\text { Equality of } \\
\text { Means }\end{array}$} \\
\hline & $\mathrm{F}$ & Sig. & $\mathrm{t}$ & Sig. \\
\hline $\begin{array}{l}\text { 1. Allocation CSR } \\
\text { programs on social } \\
\text { activities }\end{array}$ & .060 & .806 & -.019 & .984 \\
\hline $\begin{array}{l}\text { 2. proportion of } \\
\text { community } \\
\text { accepting social } \\
\text { benefits }\end{array}$ & .261 & .610 & -3.200 & $.002 *$ \\
\hline $\begin{array}{l}\text { 3. Coverage of social } \\
\text { benefits }\end{array}$ & $\begin{array}{r}3.17 \\
2\end{array}$ & .076 & -1.073 & .284 \\
\hline $\begin{array}{l}\text { 4. Self sufficiency on } \\
\text { social activities }\end{array}$ & .572 & .450 & -2.790 & $.006^{*}$ \\
\hline $\begin{array}{l}\text { 5. Supporting } \\
\text { government social } \\
\text { programs }\end{array}$ & $\begin{array}{r}2.44 \\
5\end{array}$ & .119 & -2.358 & $.019 *$ \\
\hline $\begin{array}{l}\text { 6. Changes in social } \\
\text { wealth (social } \\
\text { welfare, education } \\
\text { and community } \\
\text { health) }\end{array}$ & .571 & .451 & -3.079 & $.002 *$ \\
\hline $\begin{array}{l}\text { 7. Developing } \\
\text { community tradition } \\
\text { and culture }\end{array}$ & .167 & .683 & -1748 & .082 \\
\hline
\end{tabular}

Note: * Significant at $5 \%$

The emergence of social conflicts between the companies and communities can also be explained by stakeholder theory. According to the theory, stakeholders actually have power to control the use of the economic resources needed by the company. Stakeholder power is determined by the amount of power they have on the resources: the ability to control the use of economic resources (capital and labor), access to influential media, the ability to organize a company, or the ability to influence the consumption of goods and services produced by a company [18]. Therefore, when the stakeholder controls important economic resources, the company will react in ways that satisfy the stakeholder's desires [19]. Based on this view, the research findings mean that the society is not seen as an important and powerful stakeholder by the companies.

\section{Conclusion}

This study concluded that CSR disclosure has not been able to solve social conflicts between companies and communities. In fact, there are still different views between companies and communities on the importance of CSR elements that should be disclosed and reported by the companies. CSR elements that are seen as important by the society are considered as not so essential by the companies and vice versa. These findings imply that the society is not considered as an essential and powerful stakeholder by the companies. Consequently, social conflicts will continue to occur as long as the companies do not pay attention to the interests of the communities. Conflicts can only be reduced if the companies meet the public interests and show the public that the company's activities are legitimate and benefit the communities.

The results of this study may contribute to the importance of considering the society needs on CSR programs. Thus, government may utilise the findings as references in making policies regarding CSR programs. The findings can also be used by companies as a reference in implementing CSR programs, which are in accordance with the society demand. Finally, the results of this study may be used by communities and other stakeholders in assessing the seriousness of companies in carrying out their social and environmental responsibilities so as to solve possible social conflicts.

\section{References}

1. C. M. Loh, C. Deegan, \& R. Inglis, "The changing trends of corporate social and environmental disclosure within the Australian gambling industry". Account. Financ.55, 783-823 (2015).

2. C. Deegan, M. Rankin, \& J. Tobin, "An examination of the corporate social and environmental disclosures of BHP from 1983-1997: A test of legitimacy theory". Accounting, Audit. \{\&\} Account. J.15, 312-343 (2002).

3. C. Deegan, \& B. Gordon, "A Study of the Environmental Disclosure Practices of Australian Corporations". Account. Bus. Res.26, 187-199 (1996).

4. C. Deegan, \& M. Rankin, "Do Australian companies report environmental news objectively?: An analysis of environmental disclosures by firms prosecuted successfully by the Environmental Protection Authority". Accounting, Audit. Account. J.9, 50-67 (1996).

5. W. Jiang, \& J. K. W. Wong, "Key activity areas of corporate social responsibility (CSR) in the construction industry: A study of China". J. Clean. Prod.113, 850-860 (2016).

6. M. A. Hou, H. B. Liu, P. C. Fan, \& Z. A. Wei, "Does CSR practice pay off in East Asian firms? A metaanalytic investigation". Asia Pacific J. Manag.33, 195-228 (2016).

7. A. Romolini, S. Fissi, \& E. Gori, "Scoring CSR Reporting in Listed Companies - Evidence from Italian Best Practices", Corp. Soc. Responsib. 
Environ. Manag.21, 65-81 (2014).

8. N. Gurvitsh, \& I. Sidorova, "Survey of Sustainability Reporting Integrated into Annual Reports of Estonian Companies for the years 2007-2010: Based on Companies Listed on Tallinn Stock Exchange as of October 2011". Procedia Econ. Financ.2, 26-34 (2012).

9. T. Lambooy, R. Hordijk, \& W. Bijveld, "Communicating about integrating sustainability in corporate strategy: Motivations and regulatory environments of integrated reporting from a european and dutch perspective". Crit. Stud. Corp. Responsib. Gov. Sustain.6, 217-255 (2014).

10. P. M. Clarkson, X. Fang, Y. Li, \& G. Richardson, "The relevance of environmental disclosures: Are such disclosures incrementally informative?" $J$. Account. Public Policy32, 410-431 (2013).

11. H. Wirth, J. Kulczycka, J. Hausner, \& M. Koński, "Corporate Social Responsibility: Communication about social and environmental disclosure by large and small copper mining companies". Resour. Policy49, 53-60 (2016).

12. C. H. Cho, M. Freedman, \& D. M. Patten, "Corporate disclosure of environmental capital expenditures: A test of alternative theories". Accounting, Audit. Account. J.25, 486-507 (2012).

13. J. Guthrie, \& L. D. Parker, "Corporate Social Reporting: A Rebuttal of Legitimacy Theory".
Account. Bus. Res.19, 343-352 (1989).

14. S. O. Idowu, \& I. Papasolomou, "Are the corporate social responsibility matters based on good intentions or false pretences? An empirical study of the motivations behind the issuing of CSR reports by UK companies". Corp. Gov. Int. J. Bus. Soc.7, 136147 (2007).

15. I. Maignan, \& O. C. Ferrell, "Measuring corporate citizenship in two countries: The case of the United States and France". J. Bus. Ethics 23, 283-297 (2000).

16. D. Turker, "Measuring corporate social responsibility: A scale development study". J. Bus. Ethics85, 411-427 (2009).

17. T. Tinker, M. Neimark, \& C. Lehman, "Falling down the Hole in the Middle of the Road: Political Quietism in Corporate Social Reporting". Accounting, Audit. Account. J.4, null (1991).

18. C. Deegan, "Introduction: The legitimising effect of social and environmental disclosures-a theoretical foundation", Accounting, Audit. $\{\&\}$ Account, J,15, 282-311 (2002).

19. A. A. Ullmann, "Data in Search of a theory: a critical examination of the relationships among social performance, social disclosure and economic performance of US firms. Acad. Manag. Rev.10, 540-557 (1985). 